\title{
Views from Teachers, Children and Parents on the Reception of Refugees in Primary School in Greece
}

\author{
Marina Sounoglou \\ School of Humanities and Social Sciences \\ Dept. of Preschool Education, University of Thessaly \\ Argonafton \& Fillelinon, Volos, 38221, Greece \\ E-mail: masounoglou@ece.uth.gr \\ Aikaterini Michalopoulou \\ School of Humanities and Social Sciences \\ Dept. of Preschool Education, University of Thessaly \\ Argonafton \& Fillelinon, Volos, 38221, Greece \\ Tel: 30-24-2107-4814 E-mail:kmihal@ece.uth.gr
}

Received: March 13, 2020

doi:10.5296/jse.v10i2.16726
Accepted: April 9, $2020 \quad$ Published: May 1, 2020

URL: https://doi.org/10.5296/jse.v10i2.16726

\begin{abstract}
The refugee issue facing our country in recent years has triggered a heated debate in the social sciences about its impact on students. Most research focuses on the education of refugees and their smooth integration into society and the psychological support of families. However, there is a lack of interest in the research field for refugee reception about the teachers, pupils and parents' views and what their perspective is on this, as they directly and indirectly affect them. In this context, the present study focuses on the perspective of teachers, pupils and parents on the refugee issue, what they feel and how they perceive it, and we will examine whether the formal curriculum and informal curriculum through actions taken teachers can influence students' attitudes. In the direction indicated by the international literature, this research will be structured in a sample data collection ( 25 teachers, 25 students, 25 parents in Thessaloniki, Greece) through questionnaire and interview questions in primary school children on the perspective of teachers, students and parents on the refugee issue. The research findings are expected to illuminate the perspective of teachers, students, and parents on the current issue of refugee issue.
\end{abstract}

Keywords: refugee reception, children views, parents' views, teachers' views 


\section{Refugee phenomenon and education}

The refugee phenomenon is a significant issue of education. In Greece, the mass influx of large numbers of refugees (Eurostat, 2019) also creates a multicultural interest. The different cultural background of refugee children could be a point of convergence rather than a divergence.

The integration of young refugees into the Greek education system has been a key concern of the Ministry of Education since the beginning of 2016. In March 2016, the ministry set up a Scientific Committee with the objective to develop a plan to integrate migrant children into education in order to facilitate their wider social integration (Tzoraki, 2019).

These features overturn the data in the field of education and pose a challenge for new teaching and learning methods. The education system, and especially the classes in primary education, could play a role in order to participate actively in the process of establishing appropriate conditions for acceptance, recognition and respect for cultural pluralism and diversity.

\section{Human Rights}

The conquest of rights and their realization is a point of great importance for people and for humanity in general. Every human being has established rights. These include civil, political and social rights and are enshrined at international and national level by the constitution charters of states and international legal texts. After World War II, and with the atrocities that took place during it, they began to realize internationally that the protection and founding of Human Rights is now a crucial issue. The Charter of the United Nations (UN) and the Universal Declaration of Humanity create international texts on the protection of human rights with a significant influence such as the European Convention on Human Rights

\subsection{Human Rights Education}

Human rights education is protected and promoted in many international documents. According to the Universal Declaration of Human Rights (1948), every individual and every institution of society must seek to promote respect for human rights through education and training and to ensure their recognition and observance. Also, Article 29 of the Convention on the Rights of the Child (1989) stipulates that education must be directed to the development of respect for human rights and fundamental freedoms.

The aims of human rights education are (Bajaj 2011; Fritzsche 2005; Oomen 2009; Tibbitts 2002):

1. training in Human Rights, providing knowledge of the rules, principles, values of Human Rights and national and international mechanisms for their protection.

2. Human Rights education, which means that teaching and learning must be conducted in a way that respects the rights of both teachers and learners.

3. Education for Human Rights referred to the empowerment of individuals to enjoy the Human Rights and protect them of others. 


\section{MlMacrothink}

Journal of Studies in Education

ISSN 2162-6952 2020, Vol. 10, No. 2

According to the United Nations (UN, 2012), Human Rights Education is an ongoing process aimed at building knowledge, skills, and behaviors through education, training and information that promote and support Human Rights, promote tolerance and equality and they appreciate the difference. "It provides knowledge of Human Rights and the mechanisms that protect them, as well as the skills needed to promote, defend and apply human rights in everyday life " (UNESCO, 2009).

In recent years, international and regional initiatives have been taken to establish a legal framework for Human Rights Education (HRE), such as the World Program on Human Rights Education and Global Action, which has been adopted, in 2005 and 2010, respectively. However, HRE cannot be regarded as a unique unilateral concept and practice. Depending on the socio-political context, HRE can be introduced in a variety of ways and characterized by different ideological content and expected outcomes (Bajaj, 2011).

Human Rights Education (HRE) is the process of acquiring skills or realizing values and human rights, which aims to foster a spirit of human rights and ethical reasoning. In addition, Human Rights Education is a process of empowerment that gives individuals the skills they need to adopt social behaviors that promote "dignity and equality" within society (What are human rights, 2019).

As a tool of empowerment, Human Rights Education should challenge "dominant power relations" (Banks, 2011) and for this purpose it should be enriched with "cultural rights for citizens of different racial, linguistic groups," as required by the modern culturally diverse societies (Banks, 2011).

Education is a multidimensional and changing process that is inextricably linked to Human Rights. The introductory part of the document of the Universal Declaration of Human Rights clearly states that education must "promote respect for these rights and freedoms" in order to "ensure their universal and effective recognition" (IDF, 1948).

Osler and Starkey (1996) insisted on the benefits of education in human rights both for teachers and for students and found that Human Rights is one of the most preferred issues in international teaching.

\section{Research questions and hypotheses of the present research}

This research is structured to describe the views of a) teachers, b) pupils and c) of parents in refugee issue. In particular, the research questions of the present research are:

Q.1. What kind of perspective do teachers; students and parents take on the refugee issue based on the prevailing conditions in Greece?

Q.2. There are differences in the perspective of students, teachers and parents?

Based on the available research findings, the research hypotheses are formulated as follows with the above research questions:

H.1. Reports from teachers, students and parents are expected to vary. 


\section{MIMacrothink}

Journal of Studies in Education

ISSN 2162-6952

2020, Vol. 10, No. 2

H.2. The perspectives are expected to differentiate between teachers, students and parents.

\section{Methodology}

\subsection{Research Design, Sample, and Process}

The research sample consists of 25 teachers from the region of Thessaloniki in Greece. The regional unit of Thessaloniki is part of the administrative region of Central Macedonia. Thessaloniki has an influx of refugees. The sample for the students is comprised of 25 first grade students. The pupils come from schools in areas of high refugee flow in Thessaloniki. The sample for parents consists of 25 individuals. The parents of the sample of pupils responded to questionnaires upon arrival at school.

The data collection for the student was done on-site at the schools. The Educational Policy Institute of the Ministry of Education, Research and Religions requested admission to the sample schools. For the participation of students in research permission was requested from the parents, having secured the cooperation with the school principal. Data collection was anonymous and participants were protected. The data is only accessible to members of the research team and used exclusively for the purpose of the research.

The number of parents, teachers, and children who are potential respondents is 25 parents, 25 teachers and 25 children at first grade of elementary school. The number of parents, teachers, and children who actually responded is 23 from 25 parents, 21 from 25 teachers and 25 students from the first grade of elementary school. Parents and teachers completed paper questionnaires. The headmistress required to manage and return paper data forms from parents and teachers. The survey questions for children asked orally. There were respondents refugees and native Greeks and they respond in Greek.

The validity and reliability for the survey established with the pilot test before the survey. The pilot test was established one month before the survey in 5 children, 3 teachers and 4 parents who have chosen under a selection from a list of the Ministry of Education. The selection of the schools that took part in the research was made after a selection of 3 schools in the prefecture of Thessaloniki from a list of the Ministry of Education.

The results reviewed and coded in categories. The categories for students are 2: a. Language, b. Reception. The categories for teachers are 3: a. Language, b. Reception, c. Training. The categories for parents are 2: a. Language, b. Reception.

\section{Results}

Below we indicate the results of the answers from children, teachers and parents. The results displayed as they are coded in three categories: language, reception

\subsection{Children}

\subsubsection{Language}

Children answered about if there are any children who do not speak Greek in the classroom responded that there are children who do not speak Greek. This answer reflect the most 
common response:" there are children who do not know Greek well"

In the next question if they find it difficult to speak Greek, most of the children, specifically 20 out of 25 children answered in negative. This answer reflect the most common response "No, the games we play are simple but when they don't understand we speak English"

Also, the children answers if they learned a word from their mother language, some children responded that have learned, specifically 8 out of 25 have learned a word from their classmates. Also, 5 out of 25 have heard words from other sources such as Turkish soap operas. There were 7 children out of 25 who have not learned a word. These answers reflect the most common responses

"No, but I would like to learn"

"From movies I know some words like "tamam ".",

When children asked if they help classmates who not speak Greek when they need help, most of the children, specifically 22 children out of 25 , responded that they intend to help most of them in a few cases when they need it.

In the next question asked if they would like to learn their language, most of the children answered that they have learned some words. Few of them they wouldn't like it.

\subsubsection{Reception}

Furthermore, children answers about if they you know why are here, most of the children, specifically 18 out of 25 children answered that they did not know. However, there were 6 students that answered "they are from Syria and Turkey, they are refugees"

In the next question if they play with these kids, most of the children, specifically 21 out of 25 children, answered in positive and they are playing with them too often.

Furthermore, when they asked if they would you like to make a friend of refugee student, most of the children, specifically 21 children out of 25 answered that they have a friendship with refugee student. The other 4 responded that they are not already do that, because there was no opportunity.

In the last question if they give their toys in order to play the refugee students, all the children answered that they would give them. The answers varied depending on which toys would be. This answer reflect the most common response " Of course I would give it".

\subsection{Teachers}

The results of the teachers' profile show that half of the respondents are men and the other women. The majority are over 45 years old and they have more than 20 years of experience. All of them have a Bachelor Degree and 20\% have a Master Degree. Also, most of them know at least one foreign language and they have not trained in Human Rights Education. However, the half of them they responded in a cross-cultural seminar.

\subsubsection{Language}




\section{$\triangle$ Macrothink}

The teachers' answers about the language, curriculum and teaching methods they replied that there is not enough time to teach courses to refugees. Also, there are no curriculum propose ways and subjects for teaching refugees. However they applied different methods to the lessons that are the best approximates to the refugee students. Also, they can applied these methods in different courses such as: Greek language, Flexible zone, Mathematics, Environmental studies and Citizenship Education.

Furthermore, the teachers are divided in the opinion if the mother tongue of the refugee students make learning Greek more difficult and consequently this it will have more problems about the smooth reception in the classroom.

Also, most of them they learn words in the mother tongue of refugee students in order to facilitate their reception.

\subsubsection{Reception}

The teachers' answers about the reception indicate that they encourage refugee students to join the community in different ways. Some of them are: joining groups, integration with group activities, inclusion, inclusive practices, equal treatment, involvement in the game, creating expectations, acceptance, encouragement, hardware customization, differentiated teaching, interdisciplinary activities.

Their opinions about the reception of refugee students smooth in the classroom are divided. Most of them they believe that the cooperation with the parents of all students affect the smooth reception and they find it appropriate to organize activities in the mother tongue of refugees to ensure that they are well received after the lessons. Some of them they denied to have activities in the mother tongue due to the social reactions, children reactions, parent reactions or stigma of refugees.

They indicated that the most important inhibiting factor in the smooth reception of refugees in the host class are: the material load, the fear of the stranger, the denial of refugees and difficulties in language.

In addition, their opinions about the presence of refugee students affect the classroom climate are divided. Half of them they think that the presence of refugee students affect the climate, the other half they feel that there is no problem.

About their opinion if should be a separate school for refugee students, most of them they answered in the negative. Their feelings about the the reception classes are differentiated. Many of them they answered that classes are very good and necessary for the refugee students. Some others suggest to be better organized, to have more sections and need more staff.

\subsubsection{Training}

The views of teachers' about training are differ among them. In the first question about how ready do they feel in order to receive refugee students most of them they feel enough ready. However, there is a significant percentage that they do not feel ready or they are little ready 
in order to receive refugee students.

The teachers' responses about how many refugee students they have in class, most of them they answer that they have more than 2 students.

For the reception, all of them they feel that the training procedure help in this regard. Furthermore, most of them they are satisfied with the training that they have received and they use what they have learned in training.

However, they need more support and training. Specifically, the areas they need help to accommodate refugee students are: discipline issues, heterogeneous management and diversity management practices.

\subsection{Parents}

In this section will be presented the parents' views. The profile of parents is divided in mean and women. Most of them are over 30 years old.

\subsubsection{Language}

The teachers' views divided about language themes and if refugees should be taught their mother tongue. However, they believe that the cooperation with teachers facilitate the smooth reception of refugees in the class.

Finally, half of them they find it appropriate teachers to organize activities in the mother tongue of refugees for the proper reception.

\subsubsection{Reception}

Their opinion about the reception most of them they think that refugee students should go to day school with other students. In addition, half of them they feel that the presence of refugee students affect the classroom climate.

It is interesting that most of them they believe that there should be a separate school for refugee students. Their opinion about the host classes is poor and half of them they answered that they do not know many things about them.

Also, most of them they are positive about keeping their child friends with a refugee child. Furthermore, their opinions are divided about if they find it important for the teacher to organize a reception program.

\section{Conclusion}

Research questions about children's views of refugees prove that children have an opinion and express it. Children want to have a friendship with a refugee student. Also, they have a positive opinion to learn new words from the refugee language in order to help them.

In relation to the first hypothesis, the references of teachers, pupils and parents do indeed differ. The percentages of reports of teachers and parents do not give a definite trend.

There are teachers who believe that refugee children should not be taught their mother 
tongue. Also, they need training in order to cope with the new condition. Our findings are in accordance with the results of the research of Mogli et al. (2019) that show the lack of training of teachers working in reception class causes multiple problems, which impede educational procedures. It was found that the teachers were not able to successfully approach their refugee students so as to create the prerequisites for the children to be smoothly integrated into the Greek educational system.

Also, half of the teachers and parents believe that there is no change in the classroom climate with the presence of refugee students. However, many of them they believe that it is good to have organized by the educators reception programs for refugee parents and students. Our findings are according to the research results of Vincent \& Warren (1999) which indicate that emphasizing flexibility and the permeability of home-school boundaries would help address the concerns refugee parents have over the educational futures of their children

Furthermore, the research findings of Lunneblad (2017) reveal the different aims and strategies are used by the educators have culturally reflexive and flexible strategies aiming to empower and fostering strategies aiming to teach the parents to adjust to routines and norms in schools.

In relation to the second hypothesis the optical likely to vary between the teachers, students and parents that appeared to be linked to their answers. However, many of the teachers, students and parents have a positive attitude about the refugee reception.

This research proposal presents elements of innovation at both the theoretical and methodological level. Particularly attempts to highlight the perspective of teachers, first grade students. Also, combines descriptive with experimental method (teacher and pupil perspective on refugee issue)

This research has contributed to a small extent both at the level of basic and applied research in the fields of pedagogy and human rights education.

In particular, at the grassroots level, its results (a) engage in an international scientific debate on current theoretical questions on the refugee issue, (b) provide information on the perspective of teachers, students and parents in our country regarding the and (c) contributed to a superficial understanding of the impact of the refugee issue in our country on a particular population group such as that of pupils, of which we have little knowledge so far.

Reception of refugees in schools is an important issue for the school community. At the first level, an important criterion is the readiness of schools to receive children, the adequacy of teachers and their training in relation to intercultural competence issues (ELIAMEP, 2017).

The education and training of teachers is of particular relevance because reflected on the result of the pedagogical act. According to Michalopoulou (2018) the educator chooses based on the quality of the pedagogical result. His choices should be to help children hypothesize, research, invent, and create to encourage decision-making, problem solving, collaboration, initiative, communication and interaction. Therefore, training in approaches to Human Rights, 
intercultural, the antiracist attitude is essential to all educators since most potential and because of geopolitical changes will be required to teach classes multicultural with students from different cultural, linguistic and religious background

\section{References}

Bajaj, M. (2011). Human rights education: Ideology, location, and approaches. Human Rights Quarterly, 33(2), 481-508. https://doi.org/10.1353/hrq.2011.0019

Banks, J. (2011) Educating citizens in diverse societies, Intercultural Education, 22:4, 243-251, https://doi.org/10.1080/14675986.2011.617417

ELIAMEP. (2017) Working Paper 84/2017: The inclusion of refugees in the Greek education system https://www.eliamep.gr/en/publication.

Eurostat. (2019). Migration and migrant population statistics. Retrieved from https://ec.europa.eu/eurostat/statistics-explained/index.php/Migration_and_migrant_populatio n_statistics.

Fritzsche, K. P. (2007). What do human rights mean for citizenship education? Journal of Social Science Education, 6(2), 40-49.

Lunneblad, J. (2017). Integration of refugee children and their families in the Swedish preschool: strategies, objectives and standards. European Early Childhood Education Research Journal, 25(3), 359-369. https://doi.org/10.1080/1350293X.2017.1308162

Mayall, B. (2002). Towards a Sociology of Childhood: Thinking from Children's Lives. Buckingham: Open University Press.

Michalopoulou Aik. (2018). Early Childhood student teachers' professional development through the reflective process in their writings in Volos, Greece. Journal of Global Research in Education and Social Science, 11, 1, 40-45.

Mogli, M., Kalbeni, S., \& Stergiou, L. (2019). "The Teacher is not a Magician": Teacher Training in Greek Reception Facilities for Refugee Education. International e-Journal of Educational Studies, 4(7), 42-55. https://doi.org/10.31458/iejes.605255

Oomen, B. (2009). Mensen- en kinderrechten in het onderwijs in Nederland: Een fundamentele kwestie [Human and child rights in education in the Netherlands: A fundamental issue]. VN Fo-rum, 2009-113-20.

Osler, A., \& Starkey, H. (1996). Teacher education and human rights. New York, USA: Routledge.

Tibbitts, F. (2002). Understanding what we do: Emerging models for human rights education. International Review of Education, 48(3-4), 159-171. https://doi.org/10.1023/A:1020338300881

Tzoraki, O. (2019). A Descriptive Study of the Schooling and Higher Education Reforms in Response to the Refugees' Influx into Greece. Social Sciences, 8(3), 72. 
https://doi.org/10.3390/socsci8030072

UN. (2012) Office of the High Commissioner for Human Rights, World Programme for Human Rights Education, 2012, (HR/PUB/12/3).

UDHR. (1948). Universal declaration of human rights. Retrieved from http://www.un.org/en/universal-declaration-human-rights/

UNCRC. (1989). United Nations of Convention on the Right of the child. Geneva: United Nations.

UNESCO. (2009). World Report: Investing in Cultural Diversity and Intercultural Dialogue (Paris: UNESCO Publishing, 2009). Available at: unesdoc. UNESCO.org/im-ages/0018/001847/184755E.pdf

Vincent, C. \& Warren, S. (1999). Responding to diversity? Refugee families and schools. Paper presented at the American Educational Research Association Annual Meeting. Montreal, Canada

What are human rights, Equality and Human Rights Commission, 19 June 2019, Retrieved from https://www.equalityhuman-rights.com/en/human-rights/what-are-human-rights

\section{Appendix}

\section{Questionnaire for teachers}

A. Teacher profile

Sex

Years of service

Specialty

\section{Studies}

School type

Foreign Languages

Have you worked abroad as a school teacher? YES NO

Have you been trained in Human Rights issues? YES NO

Have you been trained in refugee phenomenon? NAI OXI

Are you trained in intercultural education issues (or multicultural) YES NO

If yes; from which university or other.

B. About teaching

1) Do you think that there is enough time to teach courses to refugees?

2) Does the Curriculum suggest ways and subjects of instruction for refugees? 


\section{IIMacrothink}

3) Do you use any method such as project, digital storytelling, narrative persuasion to facilitate the reception of refugees?

4) Do you apply any method to the lessons that reaches the best refugee students?

in what lessons?

C. About the reception

1) How do you encourage refugee students to join the community?

2) Is the reception of refugee students smooth in the classroom?

3) Does the cooperation with the parents of all students affect the smooth reception?

4) Do you find it appropriate to organize activities in the mother tongue of refugees to ensure that they are well received after the lessons?

YES NO

5) If NO for what reason? (select from the following suggestions)

Children's reactions,

Parent reactions

Social reactions

Stigma of refugees

6) Does teaching in mother tongue make learning Greek difficult and consequently smooth in the classroom?

7) What is the most important inhibiting factor in the smooth reception of refugees in the host class?

D. On training

1) How ready do you feel to receive refugee students?

2) How many refugee students do you have in class?

3) Would you learn any words in the mother tongue of refugee students to facilitate their reception?

4) Would training help in this regard?

5) In what areas do you need help to accommodate refugee students?

6) Are you satisfied with the training you received (only if you received training)?

7) Do you use what you learned in training?

E. About refugee students

Does the presence of refugee students affect the classroom climate? 
Do you think there should be a separate school for refugee students?

What do you think about the reception classes?

Should refugees be taught their mother tongue?

Questionnaire for parents

A. Parent Profile

Sex

Age

Level of education

B. About the reception

1) Do you think refugee students should go to day school with other students?

2) Does the presence of refugee students affect the classroom climate?

3) Do you think there should be a separate school for refugee students?

4) What do you think about the host classes?

5) Are you positive about having friendship your child with a refugee student?

6) Do you find it important for the teacher to organize a reception program for:

- parents

- kids

7) Should refugees be taught their mother tongue?

8) Does working with teachers facilitate the smooth reception of refugees?

9) Do you find it appropriate to organize activities in the mother tongue of refugees for their proper reception?

Interview questions for children

A. Child profile

Sex

Age

B. About the reception

1) Are there children who do not speak Greek in the classroom?

2) Do you play with these kids?

3) Do you find it difficult to speak Greek? 
4) Do you know why she/he is here?

5) Have you learned a word from their own language?

6) Helping a classmate who does not speak Greek if you need your help?

7) Would you like to make a friend of refugee?

8) Would you give your toys to another child?

9) To whom?

\section{Copyright Disclaimer}

Copyright for this article is retained by the author(s), with first publication rights granted to the journal.

This is an open-access article distributed under the terms and conditions of the Creative Commons Attribution license (http://creativecommons.org/licenses/by/3.0/). 